\title{
How Do Students Experience a Deprived Urban Area in Berlin? Empirical Reconstruction of Students' Orientations
}

\author{
Laura LUBER ${ }^{1}$ \\ University of Giessen \\ GERMANY
}

\author{
Janis FÖGELE ${ }^{2}$ \\ University of Hildesheim \\ GERMANY
}

\author{
Rainer MEHREN ${ }^{3}$ \\ University of Giessen \\ GERMANY
}

\begin{abstract}
${ }^{1}$ Corresponding author: Laura Luber, Justus-Liebig-University Gießen Department of Geography, Subject-matter education of Geography, Laura.Luber [at] geogr.uni-giessen.de; ORCID: 0000-0002-6824-6221

2Prof. Dr. Janis Fögele, University of Hildesheim Department of Geography, Subject-matter education of Geography, Foegele [at] uni-hildesheim.de; ORCID: 0000-0001-5235-7763

${ }^{3}$ Prof. Dr. Rainer Mehren, Justus-Liebig-University Gießen Department of Geography, Subject-matter education of Geography, Rainer.Mehren [at] geogr.uni-giessen.de; ORCID: 0000-0002-3667-212X
\end{abstract}

\begin{abstract}
On the one hand, this paper describes the findings from the implementation of subject-matter teaching and learning via fieldwork in a deprived area (Kottbusser Tor) of Berlin. On the other hand, the authors focus on the explicit and implicit knowledge (which we call orientations) of the students concerning this fieldwork. In a problem-oriented approach, according to the model of a social city, students develop a concept about how to renew the deprived area of Berlin. They gain a variety of new experiences, some of which raise ethical questions. Autonomous group discussions with various school classes in the age group of 14 to $16(n=30)$ were carried out after the fieldwork. The documentary method was used for data analysis which resulted in a typology of students. Concerning the orientations of the students, two excluding types of students (marginalizing type \& distancing type) and two including types (integrating type \& normalizing type) could be reconstructed. In addition to the benefit of the typology presented in this paper becoming an impulse for students to engage in self-reflection, the typology can also serve as a diagnostic tool for teachers to grasp learning conditions. Furthermore, an understanding also arises about students" orientations to support the conceptualization of fieldwork in terms of practical handling and necessary measures for its use.
\end{abstract}

\section{Keywords}

Geographical Fieldwork, Students' Orientations, Deprived Urban Area, Berlin, Documentary Method 
Although a large number of studies regard fieldwork as an effective teaching method for geographical education (Fuller et al., 2003; Fuller et al., 2006; Kent et al., 1997), it is shown that fieldwork is not an integral part of everyday school life in Germany (Lössner, 2011). In a comparative study (between 1995 and 2005) about the use of methods in geography classes, Hemmer and Hemmer (2010) point out that the frequency of use of fieldwork remains at a consistently low level. Therefore, the research groups of Professor Hemmer (University of Muenster) and Professor Mehren (University of Giessen) jointly initiated the research and development project "Berlin | between Neighborhood and Metropolis". Part of the project's aim was to develop a geographical fieldwork concept covering various urban geography topics; the concept had to be suitable for practical use based on findings from subject-matter teaching and learning. The project aim is necessary because empirical findings about the implementation of fieldwork reveal that teachers rarely follow the recommendations to complete fieldwork (Remmen \& Frøyland, 2014; Oost et al., 2011; Lössner, 2011). Thus, both nationally and internationally, it appears that superficial geographical learning often takes place on field trips in the sense of a "look and see" attitude (Lee, 2020). Concerning Berlin, the city is popular for field trips with secondary school students, particularly because of its role as the capital city and as a divided city until reunification (Dannenberg, 2013). An emphasized analysis of geographical issues, including geographical concepts, methods or theories, however, remains an ongoing demand (eg. Bette et al., 2015a). On the other hand, empirical research should be conducted on fieldwork concepts (Fögele et al., 2014; Bette et al., 2015a, b). Up to now, findings hardly take into account students' perspectives and their experiences of fieldwork (Nairn, 2000; Lössner, 2011). Overall, it is considered that students generally evaluate fieldwork as a valuable experience (Boyle et al., 2007; Dunphy \& Spellman, 2009; Fuller et al., 2003; Hemmer \& Hemmer, 2010; Lössner, 2011). However, studies dealing in more detail with the experience-based learning of students on fieldwork highlight that learning in deprived or low-income areas does not always correspond to the intended purpose of the task (Hope, 2009; Nairn, 2005) although it is an important experience for students (Elwood, 2004; Hope, 2009). Such studies indicate that "existing knowledge and conceptual frameworks" like students' conceptions about a specific neighborhood (Elwood, 2004, p. 55) or "prior beliefs" (Nairn, 2005, p. 305) will influence how students react to fieldwork. In addition to explicit knowledge, these studies also suggest the relevance of implicit knowledge, which is effective in and guides learning in the field - for example, when Nairn (2005) stated that a student implicitly constructed her life as normality and had no direct access to experience and "truth". The authors of the study do not assume an "objective truth" either, but rather a collective, implicit knowledge; and based on Bohnsack (2010) we use the term "orientation" which, in addition to explicit knowledge, contributes to the formation of social reality from the students 'perspective. In contrast to the aforementioned studies, from which it tends not to become exactly evident how the findings were obtained in a methodologically controlled manner, the authors following the assumption that implicit knowledge in the sense of orientations goes 
beyond the individual, i. e. is primarily collective and not individually founded (Mannheim, 1980; Bohnsack, 2010) ${ }^{4}$. In particular, the authors regard the concept of orientations, which reveals deeper, socially formed patterns beyond individual statements and justifications of students (Kleemann et al., 2013), as an approach to gain more detailed information to explain the different effects of fieldwork to deprived areas on students. The following example is intended to illustrate this point: The area of Kottbusser Tor, for example, can be clearly defined from a topographic or spatial planning perspective. The inhabitants of the Kottbusser Tor, however, ascribe a different meaning to the area, based on structure-identical experiences of their everyday practice (they form a so-called "conjunctive experiential space"; Bohnsack, 2010, p. 103). These meanings are based on essentially shared knowledge structures and thought patterns and differ from the definitional way, i.e. explicit, theoretical knowledge (Mannheim, 1980). This conjunctive knowledge is not directly accessible to outsiders and is primarily atheoretical, i.e. implicit, for the inhabitants themselves (Mannheim, 1980; Bohnsack, 2007; 2010). It is experience-based and habitualised knowledge, as it is acquired based on shared experience (Mannheim, 1980).

To be understood as a field-specific habitus (Helsper, 2018), students also have experiences that are structure-identical - for example, certain classes or the peer group can form conjunctive experiential spaces within which specific orientations guide action (Kleemann et al., 2013). For students, these orientations represent a kind of self-evident, implicit knowledge that guides their activities (Bohnsack, 2010). Transferred to the fieldwork, orientations tend to guide the students' action practice (Moritz, 2016), and respectively become important in the students' encounter with Kottbusser Tor. Students integrate experiences gained during fieldwork activity (including behavior of and talks with inhabitants) in their existing (explicit and implicit) knowledge (ibid.). Following this logic, orientations influence the perception and experience of the fieldwork in a deprived area and thus also their geographical learning. In other words, the learning processes of students are not exclusively influenced by prior knowledge and students' preconceptions (directly related to the geographical concept) (Lane \& Coutts, 2015). They are additionally influenced by orientations which are partly non-subject-specific and implicit. This implies that the realization of an intended learning experience especially takes place if the implicit as well as the explicit conditions of the students are taken into account. In the field of subject-matter teaching and learning research, the importance of orientations has been empirically shown several times (Hofmann, 2015; Fögele, 2016). Following this assumption, the empirical investigation focusses on the

${ }^{4}$ The concept of orientation corresponds to the term of habitus (Bourdieu, 1997) and is largely used as a synonym in the context of the underlying theory (Bohnsack, 2010). The concept of Habitus implies collectivity (Helsper, 2018) and can be understood as a deeply embedded system of orientations that guide action (Bohnsack, 2010). 
students' views on the fieldwork, as well as their ways of dealing with it. The central question is which typical orientations guide the students' action practice in a deprived area, or rather which orientations become apparent in the context of the fieldwork. For the explication of these orientations, open questions, which are situated between explicit and implicit knowledge and provide access to the students' orientations, are used first: How did students' face the fieldwork area? What did they see and what did they experience? Which (content-related) relevance did the students perceive?

Following this approach, a reconstructive-qualitative research methodology is required, which considers the encounter between students and fieldwork in its complexity. The methodological approach used in this study is the documentary method (Bohnsack, 2007; 2010). The method's main concern is to explicate the action-guiding (implicit) orientations and thus to investigate which collective patterns of thought and action exist (Bohnsack, 2010; Kleemann et al., 2013) and what practical consequences result for the geographical learning of the students in a deprived area. The circumstance that the students have a shared history (conjunctive experiential space) is exploited by giving the students the opportunity to communicate openly via group discussions (data collection methodology) and thus express their own relevance structures in which the orientations are documented (Loos \& Schäffer, 2001). Based on the student's field experience, the authors reconstruct the orientations of the participants within the framework of a typology. The study offers some important insights into students' explicit and implicit knowledge, which is effective in the practice of experiencing fieldwork in a deprived area. All in all, these findings provide a benefit for the further development of learning processes in the context of urban fieldwork. First, this paper presents an overview of literature. Afterwards, the fieldwork concept is described, followed by the presentation of the study design. The central results of the study are presented subsequently.

\section{Theoretical Framework}

\section{The "Kottbusser Tor - Development of A Multiple Perspective Urbanrenewalproject" Fieldwork: The Fieldwork Area}

The Kottbusser Tor is a sub-center of the Berlin-Kreuzberg district. From hereon Kottbusser Tor will be referred to as "Kotti". Kotti is characterized by the "Neue Kottbusser Zentrum" (NKZ), a residential complex with 295 apartments with more than 1,200 residents. Around 70\% of them have a migration background (AtracheYounes, Bosa \& Hilse, 2017). Kotti is an example of the misguided redevelopment policy of the 1960s and 1970s, which was drawn up on models such as demolition and reconstruction, the car-friendly city, or urbanism by means of density (Findling, 2003; Richter-Rethwisch, 2014). The city administration planned a new residential concept without considering the needs of the residents. A unilateral demographic structure and income poverty are results of segregation processes (Beer \& Musch, 2003; Richter-Rethwisch, 2014). Rising rents reinforce the problem (Bock \& 
Pappenberg, 2018). The area surrounding the Kotti is characterized by a multitude of challenges for urban development (Atrache-Younes et al., 2017):

- Education \& youth: Overstressed care and educational facilities (such as the need for infrastructural measures; qualitative improvement of educational system transitions and extracurricular support offers);

- Work \& economy: High unemployment rates (especially among youths) and few chances of reintegration long-term unemployed people into the labour market because of various problems (for example, age, qualification level); Low levels of networking among local businesses and their involvement in district development;

- Neighborhood: Despite the fact that the commitment of local residents is increasing, there are still difficulties in integrating many residents with a migration background into district development and participation processes because of their tendency towards withdrawing into a circle of friends and family;

- Public space: Low sojourn quality as a result of overuse and negligence of the housing environment and public spaces; Open alcohol and drug scene/abuse with increasing crime rates since 2015.

\section{Conceptual Framework of the Fieldwork: The "Social City" Model}

In Germany, segregation-related action plans tend to focus primarily on improving deprived areas rather than on a new mix of inhabitants in these areas. From the perspective of spatial planning, it is therefore relevant to consider the residents' perspectives as well in order to initiate a positive development of the residents' quality of life in corresponding areas (Sieben, 2010). The so-called "Districts with particular need for development - the social city" program initiated by the German Federal Ministry has existed since 1999. Its purpose is to give fresh development impetus to areas which are in a downward spiral (Eltges \& Kocks, 2015). The so-called "overburdened neighborhoods" identifiable by low income, high unemployment, a high percentage of residents with a history of immigration, poor structures, lack of neighbourly help (Krings-Heckemeier \& Pfeiffer, 1998) are often characteristic of such quarters. The "social city" approach tries to prevent further spatial stabilization of the status quo of marginalized areas and the accelerating segregation of the inner-city population. The aim is for socially responsible urban development to occur in which the local population is entitled to comprehensive information, protection and participatory rights. The living conditions in the problematic quarters are to be improved from inside out (bottomup). Thus, the social conditions themselves become the object of measures (for example, by promoting neighborhood initiatives or social facilities) instead of investing primarily in structural measures (Eltges \& Kocks, 2015). The efforts do not focus on mobilization against, rather than on activation for projects. It focusses on the "transformation from a social case to a social place" (Becker \& Löhr, 2002, n. pag.), from being alongside each other to being together. Thus, the program represents an approach to promoting a new civil society and new civil players on a 
local level (Walther, 2007; Becker \& Löhr, 2002). The local Quartiersmanagement (neighborhood management) institutionalizes this process and pursues a participative approach, in which attempts are made to bring together diverse protagonists (such as non-organized residents, local initiatives, city planners) and to involve these in projects (Atrache-Younes et al., 2017).

\section{Subject-Matter Teaching and Learning Design Principles of Fieldwork}

For the purpose of designing a student-oriented fieldwork, both empirical findings on effective learning on field work as well as students' interests and attitudes should be taken into account (Hemmer \& Uphues, 2008).

The results of a survey $(n=610)$ regarding fieldwork in Berlin showed that students are hardly interested in spatial planning issues (mean $=2.67$ on a 5 -point Likert-scale) whereas issues associated with the daily life of local people are rated higher (mean $=3.35$ ) (Bette et al., 2015a). Considering working methods, independent work or communication plays a particularly important role for students (Bette et al., 2015b).

In addition to the students' demand for self-activity when learning in the field (Bette et al., 2015b; Lössner, 2011), empirical findings also indicated the benefit of student-centered approaches (Kent et al., 1997; Oost et al., 2011; Remmen \& Frøyland, 2014). Student-centered approaches are often associated with deep learning which is characterized by a high motivation and a deeper understanding of concepts (Remmen \& Frøyland, 2014), but also with a stronger personal responsibility of their learning experience (Hemmer \& Uphues, 2008). Acquiring and analyzing field data in a problem-oriented approach is seen as a way of initiating deep learning (Kent et al., 1997; Tonts, 2011). However, deep learning is not necessarily stimulated by taking students into the field (Kent et al., 1997; Dummer et al., 2008; Fuller et al., 2006). In addition to active learning settings, some researchers also emphasize the importance of direct experience gained during fieldwork (Lee, 2020; Hope, 2009; Elwood, 2004). Up to now, a few studies have investigated the importance of direct experience during fieldwork in human geography (Elwood, 2004; Hope, 2009; Nairn, 2005). The data situation can be considered divergent. Elwood (2004) claimed that visiting deprived areas can be a tremendously important experience for students. However, she also mentioned that it is not possible to predict exactly what will happen locally or how the students will interpret the situation during the fieldwork activity (Elwood, 2004). Accordingly, she attributed a key part to critical reflection before and afterwards. This reflection process should include the knowledge of the students. Nairn (2005) faces these findings with scrutiny and supports her argument with the findings of Scott (1992) who warns that "experience of 'the real world' is never transparent and unmediated" (Scott, 1992; cit. in Nairn, 2005, p. 293). She demonstrated that fieldwork experience of students who visited a low-income area reinforced prior preconceptions rather than enhanced their understanding. Nairn's $(2005$, p. 306) point is that "if direct experience does not provide an effective way of challenging 
students' preconceptions then trading on direct experience as the only pedagogical tool is flawed in theory and practice". In this context, Nairn's findings showed limitations of learning during fieldwork by emphasizing on how the construction of the self can prevent understanding about "the other". Hope (2009) refers directly to Nairn (2005) and partially supported her findings, but Hope (2009) also pointed out that on the one hand direct experience can certainly challenge students' preconceptions. On the other hand, she showed that students are able to understand the complexity of geographical issues through affective responses or active engagement with geographical issues when gaining a sense of place. Hope attributes this to a significant relationship between direct experience with others and the emotional response to others. Hope (2009, p. 179) ascribes different learning outcomes to different abilities "to be attentive and open to others". In doing so, she refers, at least indirectly, to the necessity of reflexive abilities as prerequisites for students (Dewey, 1910). Considering all these findings in total, it seems that direct experience does not automatically lead to learning effects, but if students have certain reflexive abilities, strong positive learning effects might be expected.

\section{The Fieldwork Concepts}

The following fieldwork concept (Table 1) was designed with regard to the challenges of (urban) geographical fieldwork in general and in particular to the findings about Berlin. The fieldwork is aimed at the features of the social city concept with links to student interest about geographical issues related to spatial planning with working methods/locations which require student activity. The fieldwork also enables an encounter with the everyday life of local people to maximize deeper learning (Kern \& Carpenter, 1986; Remmen \& Frøyland, 2014). The main concern of the fieldwork is to enhance students' appreciation of a multiperspective urban renewal concept for the deprived area at "Kotti" in collaboration with and from the perspective of the inhabitants (in the sense that their needs are taken into account). This didactic approach is appropriate as it creates opportunities to discover, understand and comprehend the complexity of the living environment and the concrete realities of the inhabitants at Kotti. Knowledge is therefore not generated by analyzing data about people at a great distance but with the residents. The implemented method of "role fieldwork" is intended to illustrate different perspectives about Kotti to the students by initiating a change of perspective (Böing \& Sachs, 2009). Through a change of perspective, students should be able to get in contact with different realities of life instead of talking about "others". Especially in the context of critical reflection, the change of perspective is of great importance because on the one hand the students' own subjectivity is accepted and on the other hand new perspectives are embraced to broaden the own ones (Gryl, 2013). Therefore, the groups are each provided with information units which can be used individually to gain a deeper understanding of their perspectives. Putting oneself into a perspective requires not only empathy but also the willingness to get involved in new and unfamiliar situations. In order to make this engagement easier, students are offered the choice of meeting with one of two possible experts having an internal 
perspective: either with a city planner from the Quartiersmanagement BerlinKreuzberg or with a social worker from the neighborhood association Kotti e.V. Based on this preparation, the fieldwork is also designed to ensure students have face-to-face contact with residents of Kotti. From the students' perspective, meeting others is a valuable aspect (Bette et al. 2015a; Tonts, 2011). The concept thus lives up to the social city approach by giving the residents themselves the opportunity to comment on aspects relevant to them. Each group accordingly chooses one or more persons in their protagonist group and discusses intended redevelopment approaches with them (Pawson \& Teather, 2002). The interview guide consists of three simple questions ("What do you like about the Kotti?", "What disturbs you about the Kotti?" and "What wishes do you have for the Kotti?").

Based on the knowledge and insight gained, a panel discussion takes place as a subsequent step. Its objective is to reach a consensual redevelopment approach at the end, which includes all perspectives. A critical reflection also integrating students' own knowledge and ideas (Elwood, 2004) should show that understanding about the redevelopment of Kotti has changed during the course of the fieldwork.

Table 1

Course of The Fieldwork

\begin{tabular}{|c|c|c|}
\hline Location & Thematic-methodical key aspects & Media \\
\hline $\begin{array}{l}\text { Location } 1 \\
\text { Advertising } \\
\text { pillar at the } \\
\text { corner of } \\
\text { Adalbertstraße/ } \\
\text { Reichenberger } \\
\text { Street (with } \\
\text { participants' } \\
\text { backs towards } \\
\text { the meeting } \\
\text { point of the } \\
\text { homeless) }\end{array}$ & $\begin{array}{l}\text { Introductory phase } \\
\text { Orientation and Observation } \\
\text { Students get an initial impression of the Kotti and } \\
\text { spontaneously verbalize redevelopment measures. The first } \\
\text { impression will be noted on the poster I. } \\
\text { Change of perspective } \\
\text { The students' awareness of the different perspectives on the } \\
\text { Kotti is raised by... } \\
\text { Questioning the redevelopment measures mentioned above by } \\
\text { taking a broader view of aroup of homeless people. } \\
\text { Naming the different protagonists of the area at the Kotti (e.g. } \\
\text { resident, Turkish vegetable vendor, mother and child, } \\
\text { homeless). } \\
\text { Problematization } \\
\text { Students develop the problem question "What would a } \\
\text { revitalization concept for this square look like if the various } \\
\text { points of view of the different protagonists of the Kotti area are } \\
\text { taken into consideration?" } \\
\text { Transparency of objectives } \\
\text { The teacher presents the objective, the geographical relevance } \\
\text { and the structure of the fieldwork. Students are divided into six } \\
\text { groups and slip into the perspective of a protagonist of their } \\
\text { choice. }\end{array}$ & $\begin{array}{l}\text { Map, } \\
\text { Poster I, } \\
\text { permanent } \\
\text { marker }\end{array}$ \\
\hline $\begin{array}{l}\text { Location } 2 \\
\text { Balcony of the } \\
\text { Neue Kottbuser }\end{array}$ & $\begin{array}{l}\text { Capturing of occupied partial areas (Expert groups) } \\
\text { In an aerial photograph, the students colour the subspaces of } \\
\text { the Kottbusser Tor occupied by their protagonist. }\end{array}$ & $\begin{array}{l}\text { DIN A4 map } \\
\text { of Kotti (M 1) }\end{array}$ \\
\hline
\end{tabular}




\begin{tabular}{|c|c|c|}
\hline $\begin{array}{l}\text { Zentrum (NKZ) } \\
\text { above Adalbert } \\
\text { street }\end{array}$ & $\begin{array}{l}\text { Development of a map of togetherness, juxtaposition, and } \\
\text { opposition (All together) } \\
\text { The students work on the conflict potential of selected } \\
\text { subspaces by creating and analyzing a map of togetherness, } \\
\text { juxtaposition, and opposition in mixed groups. }\end{array}$ & $\begin{array}{l}\text { for each } \\
\text { participant } \\
\text { DIN A3- Map } \\
\text { (M1 } \\
\text { enlarged) for } \\
\text { each group }\end{array}$ \\
\hline $\begin{array}{l}\text { Location } 3 \\
\text { Playground at } \\
\text { Adalbert street } \\
\text { (behind the } \\
\text { library) }\end{array}$ & $\begin{array}{l}\text { Development of the interests of the different spatial } \\
\text { protagonists } \\
\text { Transparency of objective } \\
\text { Regarding the results obtained, the teacher refers to the } \\
\text { objective. } \\
\text { Stage 1: Teacher lecture on the development of the Kotti } \\
\text { The teacher explains the formation and the development } \\
\text { process with the help of material. }\end{array}$ & $\begin{array}{l}\text { M2-M4 } \\
\text { Information } \\
\text { sheet (M5) }\end{array}$ \\
\hline $\begin{array}{l}\text { Location } 4 \\
\text { FHXB-Museum }\end{array}$ & $\begin{array}{l}\text { Stage 2: Visit to the FHXB (=Friedrichshain-Kreuzberg)- } \\
\text { Museum } \\
\text { The students explore the museum independently in their } \\
\text { groups. }\end{array}$ & \\
\hline $\begin{array}{l}\text { Location } 5 \\
\text { Neighborhood } \\
\text { café }\end{array}$ & $\begin{array}{l}\text { Stage 3: Expert discussion } \\
\text { The students have an expert discussion with a social worker of } \\
\text { the Kotti neighborhood association. }\end{array}$ & \\
\hline $\begin{array}{l}\text { Location } 6 \\
\text { Place around the } \\
\text { Kottbusser Tor }\end{array}$ & $\begin{array}{l}\text { Stage } 4 \text { : Interview with the real protagonists of Kotti } \\
\text { The students compare the perspective they have developed } \\
\text { with those of real protagonists. }\end{array}$ & $\begin{array}{l}\text { Interview } \\
\text { guide } \\
\text { (M6) }\end{array}$ \\
\hline $\begin{array}{l}\text { Location } 7 \\
\text { Dresdener street } \\
126 \\
\text { (playground) }\end{array}$ & $\begin{array}{l}\text { Development of a multi-perspective renewal concept } \\
\text { Discussion } \\
\text { In a panel discussion, the students develop a multi-perspective } \\
\text { renewal concept and achieve a consensus. } \\
\text { Completion of site work } \\
\text { The students write down the jointly developed renewal } \\
\text { measures on the poster II. }\end{array}$ & Poster II \\
\hline $\begin{array}{l}\text { Location } 8 \\
\text { Dresdener street } \\
12 \text { (with a view } \\
\text { of the } \\
\text { neighborhood } \\
\text { management } \\
\text { office) }\end{array}$ & $\begin{array}{l}\text { Reflection and consolidation } \\
\text { Assessment of the results } \\
\text { The students assess their concepts by } \\
\text { comparing the posters, they have produced } \\
\text { assigning the two cards "indifferent" (=gleichgültig) and } \\
\text { "equally valid" (=gleich gültig) to the posters } \\
\text { Comparison of results } \\
\text { The students explain to what extent their measures on posters } \\
\text { I and II are consistent with the "Social City" model by reading } \\
\text { an information text. } \\
\text { Consolidation the teacher explains the approach of } \\
\text { neighborhood management and presents selected project } \\
\text { measures. }\end{array}$ & $\begin{array}{l}\text { Poster I and } \\
\text { II; } \\
\text { M5, M6 }\end{array}$ \\
\hline
\end{tabular}

\section{Methods}

The fieldwork was carried out with the typical target group, secondary school students (age 14-16) (Bette et al., 2015a). The participants consisted of 30 students from various regions in Germany (rural-urban / western and southern Germany). To investigate the orientations of the students concerning the fieldwork, group discussions were used as a data gathering tool. In order to form maximum contrasts 
for the data analysis, a higher number of groups were interviewed ( $n=7$ groups) instead of the recommendation found in the literature ( $n=3-5$ groups) (Lamnek, 2005). After the fieldwork, students came together in small groups of five or six participants. These were so-called "real groups" (e.g. befriended students within the class), which were formed voluntarily (Fögele, 2016). This offers the advantage that a conjunctive space of experience can be assumed, which is characterized by the fact that the group participants have structure-identical experiences, which, however, need not have been made together (Loos \& Schäffer, 2001). Accordingly, the object of study is not the individual experience of the students or a specific group, but the orientation presented collectively by the group participants, which is based on their structure-identical experiences (Fögele, 2016).

The research group of the authors conducted group discussions of about 30-60 minutes. According to Loos \& Schäffer (2001), a group discussion is seen as an autonomous exchange of ideas. Thus, the group discussions were not given an interview guide, rather the participants had the opportunity to express the topics according to their own ideas and system of relevance (Bohnsack, 2010; Loos \& Schäffer, 2001). In reference to the main concern of explicating students' orientations relevant to the fieldwork, the documentary method (Bohnsack, 2007; 2010) was used for analyzing data 5 .

This approach follows Mannheim's (1980) "Praxeological Sociology of Knowledge" and distinguishes between communicative/theoretical knowledge on the one hand and conjunctive/atheoretical knowledge on the other. The latter one is the kind of knowledge that gives orientation to action and becomes apparent in a conjunctive experiential space (Bohnsack, 2010). Because of its reconstructive approach, the documentary method claims to offer methodically controlled access to the implicit knowledge by apprehending the conjunctive space of experience (Bohnsack, 2010). The fieldwork can be understood as part of a shared history of experience (Kleemann et al., 2013). Each group discusses the topics in their own way. In the way the topics are discussed the (implicit) orientations are documented. These orientations do not have an objective but a conjunctive validity (Mannheim, 1980) and do not have to be communicated explicitly by the participants because they metaphorically express them in their narratives and implicitly refer to orientations. Insofar as the students embody the same history, those who have incorporated the same habitus-schemes can understand each other without actually being able to name them (Bohnsack, 2013). For example, a statement about the change of perspective (which the students attribute a high relevance in the group discussions) in the form of a small hint in the conversation is enough for the students of group "Mittelstadt" to initiate common remembrance (Kleemann et al., 2013). In the narratives of how the group perceived the change in perspective, their shared

5 The chapter on methods is partly based on Fögele, Luber \& Mehren 2019; for further methodological explanations see also Fögele et al., 2019. 
orientation (=hierarchy orientation; see results, Type 1) becomes apparent. Comparative on a thematic level, the group "Global city" also talks about the change of perspective, but in a completely different way. Behind the statements of the Global city group there is also a shared orientation (on distancing; see findings, Type 2), on the basis of which the students communicate and which is presented collectively without being named by the students. These orientations can be reconstructed, comparatively from the students' statements, using the research method. Therefore, the documentary method follows a basic principle of sequential steps (an exemplary interpretation can be found in the Appendix). At first, the group discussions were transcribed in detail. In order to grant the protection of personal rights, an anonymization was carried out. Afterwards, relevant text passages were selected according to the criteria typical for the documentary method. Such passages are (Bohnsack, 2007, 2010; Przyborski \& Wohlrab-Sahr, 2009):

- the opening passage: With what topic do the groups commence in response to the impulse "you had fieldwork at Kotti today. Tell us about your experience"? (e.g. organizational aspects of the fieldwork, contextual aspects as the spatial perception of Kotti...?);

- metaphoric density: Text passages in which strong metaphorical language is used (e.g. "even the rain sticks at Kotti"; making Kotti "a repository for nuclear waste");

- interactive density: Text passages with frequent changes of speakers;

- the relevance of content for the research question (due to the openness of the discussion, consistency can't be necessarily granted here) (e.g. encounter with the Kotti; spatial perception of the Kotti; passages about fieldwork components or contents);

- comparability: Are similar aspects also dealt with in other group discussions?

Through these steps, already existing constructions that are relevant for the students are reconstructed, whereby the result of the documentary analysis can be understood as a second-order construction (Kleemann et al., 2013). Accordingly, the reconstruction of the orientations took place in joint research workshops of the authors to continuously expose them to scientific criticism through a multiperspective interpretation (Applis et al., 2015; Reichertz, 2013). In a first step (the formulating interpretation) the focus is on WHAT students talk about. Therefore, the explicitly expressed passages are paraphrased in detail. In a second step (the reflecting interpretation), there is a transition from asking what the topic is to HOW the topic is elaborated on (What does the statement implicitly express about orientations?) (Przyborski \& Wohlrab-Sahr, 2009). Particular focus was placed on the organization of discourse (oppositional, diverging, parallelizing, univocal and antithetical) and the discourse progression. In the discourse progression, an examination is made of how topics are set (proposition) and reacted to (subsequent proposition) by the group members, how topics are presented (elaboration) and 
how aspects are summarized (conclusion) (Kleemann et al., 2013). Positive (such preferences are shown in narratives; for example, Type 2; Learning about buildings) and negative counter poles (oppositions shown in narratives; for example, Type 2; Interviewing inhabitants), as well as the enactment potential (opportunity of practical realization of one's own orientation) frame the orientation of the students (Bohnsack, 2010; Kleemann et al., 2013). The process takes place iteratively to identify the similarities and differences of the orientations thus reconstructed and to be able to prove their relevance beyond individual cases. This so-called comparative analysis is made case-internal and cross-case, at the level of topics treated in a comparable way (for example, the change of perspective, spatial perception), as well as at the level of similar and distinguishable orientations (for example. hierarchy, distancing). The orientations reconstructed were subsequently condensed in a meaning-genetic typology (Bohnsack, 2010). The typology can be understood as a topic-specific, case-comparative abstraction of the orientations reconstructed in the analysis. The cases grouped into types have common specific orientations that distinguish them from other types (Kleemann et al., 2013).

\section{Selected Findings}

The fieldwork was designed with consideration of findings from state-of-the-art subject-matter teaching and learning. However, this provides limited evidence about how fieldwork is perceived by students. The reception shows their underlying orientations. The representation of the types ${ }^{6}$ illustrates which sub-topics are relevant for the students when they are dealing with the conduct of fieldwork in a deprived area in Berlin. Within group discussions, "otherness" initially proved to be a recurring theme with high interactive and metaphoric density across almost all groups. The way the topic was dealt with, however, proved to be different, which initially indicated different underlying orientations. Starting from this perception and experience of the students described in narratives, the further analyses were carried out on an implicit level. Thus, four different types were reconstructed (see Fig. 1, cf. also Luber, 2015; Fögele et al., 2016). Figure 1 below provides an overview of Types $1-4$. These types are then discussed using exemplary excerpts of individual group discussions (GD).

6The types shown are so-called "ideal types" (Nentwig-Gesemann, 2013). This does not imply normativity, but means an abstraction of empirical reality, which does not occur in pure form, but rather represents an idealized representation of real cases. 


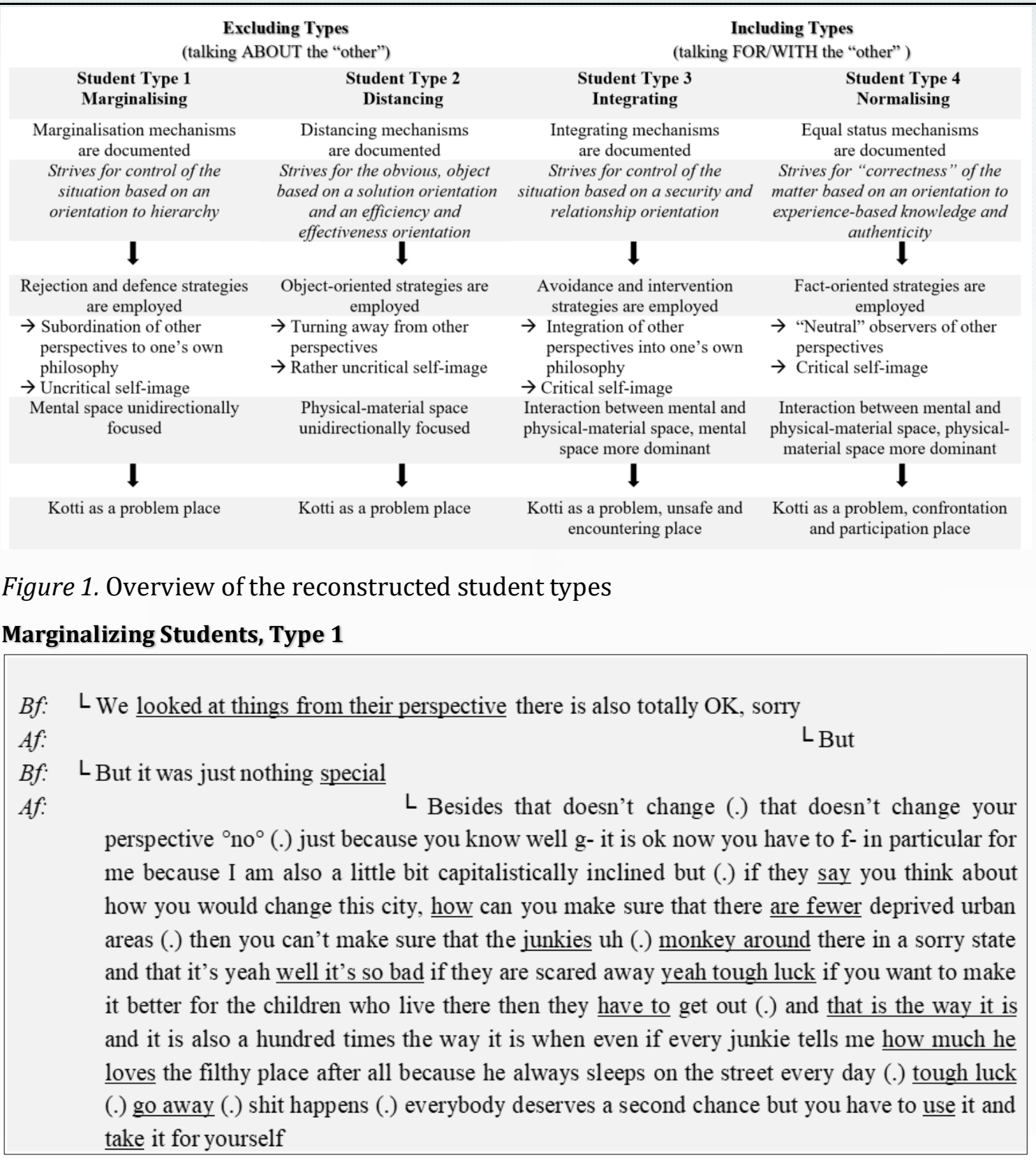

Figure 2. Remarks typical of the marginalizing student type (GD Mittelstadt, 220-259)7

In the excerpt above, the students talk about the change of perspective in a judgmental way. According to Bf, the task was carried out yet at the same time it is emphasized and rated negatively that this is "nothing special". What becomes clear here is mainly the lack of understanding about perspectives that do not correspond with one's own. Such perspectives are devalued. The possibility of one's own perspective changing are explicitly negated ("doesn't change your perspective"). Consequently, the perspective of the protagonists is subordinated ("tough luck, go

${ }^{7}$ The presented excerpts from the group discussions are all translations from the original language. 
away, shit happens"). A hierarchy of opinion prevails - the students are convinced they possess the knowledge necessary to do it better. This is shown at an explicit level by the certainty of their remarks ("and that's the way it is"). An orientation towards social order becomes apparent, which is linked to personal responsibility and the ability to assert oneself; although everyone should deserve "a second chance", it has to be taken. The responsibility for their situation is attributed to the protagonists themselves. In the sense of blaming the disadvantaged, this can be understood as an internalized expression of dominance (Fleischer, 2016).

"Otherness", for Type 1 students, poses a reason for marginalization. There are clear ideas about which behavior or lifestyle is to be regarded as appropriate and which is not. If the latter one is the case then representatives from Type 1 will consider marginalization as legitimate. In such a context, Type 1 students will regard their view of the world as set-in stone - there is a lack of openness to other points of view (Hope, 2009), which leads to a narrow way of thinking and prevents geographical learning. Attempts to comprehend protagonists' views are less evident. Consequently, one's own philosophy is not a matter of reflection. The allegations of similarity and difference that form this basis tend to be undifferentiated. Type 1 students see themselves as part of a center consisting of "normal guys" (Nairn, 2005). In contrast, everything lying outside is "otherness". Other perspectives are met with a lack of understanding and prejudices. As a result, in this orientation, protagonists who do not comply with their standards of normality are linked to stereotypical behavioral descriptions (GD Großstadt "and I was just thinking he was going to pull a knife out of his pocket"). Here a divergence can be seen between the orientation of the students and the perspective of spatial planning (consider the residents' perspectives; bottom-up; Sieben, 2010). For Type 1 students this results in a tendency to demonstrate negative attitudes towards fieldwork (Fuller et al., 2003). Consequently, Type 1 students consider the interviews pointless in the course of discussions (GD Großstadt "it was clear that nothing of value would come out of it") and that one does not have to be at Kotti to know "that those are junkies and homeless" (GD Mittelstadt) (=talking ABOUT "others").

What has been experienced finds expression in these thought patterns and is stabilized within the group. As a result, the distinction from the "marginal group" is intensified (Nairn, 2005). Type 1 students do not consider contrary concepts. The subjectivity and individuality of a person tend not to be recognized and the difference between them is emphasized through their denigration. Type 1 students continuously position themselves in the center of the group discussion, focused on what they have learned or felt (GD Großstadt "this is now extremely embarrassing for you"). To some extent, there is also an implicit appreciation of themselves (GD Großstadt "and you just notice that they see that you don't belong there"). 


\section{Distancing Students, Type 2}

\begin{tabular}{|c|c|}
\hline $\mathrm{Cm}:$ & $\begin{array}{l}\text { Well the only thing that I really found interesting was actually only then when he told us about } \\
\text { the history of this building and the whole neighbourhood, I found that right interesting but the } \\
\text { other stuff it was rather a little bit unnecessary (.) yeah }\end{array}$ \\
\hline$Y:$ & Ok what is the other stuff? \\
\hline $\mathrm{Cm}:$ & $\begin{array}{l}\text { Yeah just that with this (.) the thing perhaps with being in their shoes okay but then in that office } \\
\text { that could have just been touched on or that we then got those maps there and then got to colour } \\
\text { it in and then somehow supposed to conclude where the approximately where the problem, } \\
\text { where the problem areas were or where there could be conflicts I found that a little yeah too } \\
\text { somehow boring because you really don't know at all what their life is like you can only just } \\
\text { imagine it so and then go and beating your brains out over it is also not right somehow. I would } \\
\text { have preferred rather to learn even more about the history or would have somehow gone into } \\
\text { special buildings }\end{array}$ \\
\hline$Y:$ & Then you would have liked to have had some more other stuff? \\
\hline Bm: & Yeah \\
\hline $\mathrm{Cm}:$ & L Yeah just more about the history or some \\
\hline Bm: & $\mathrm{L}$ about buildings yeah too \\
\hline $\mathrm{Cm}:$ & $\begin{array}{l}\text { LYeah (.) the } \\
\text { buildings just because while you can also say something about people but buildings actually } \\
\text { express a lot (2) }\end{array}$ \\
\hline$Y:$ & $\begin{array}{l}\text { Ok maybe you could just go back to it once again briefly you said somehow that you had spoken } \\
\text { with the people there }\end{array}$ \\
\hline Am: & Yeah well you just have to eh look around you turn $360^{\circ}$ so to spea \\
\hline$Y:$ & Ok. \\
\hline Am: & $\begin{array}{l}\text { You could then see more or less what it is or also we had a kind of sheet where that where the uh } \\
\text { view from up above was printed on it and there you could also easily see you could find yourself }\end{array}$ \\
\hline $\mathrm{Cm}:$ & $\begin{array}{l}\text { It was like that with us too with the bicycle in the bicycle group. We then finally found one a } \\
\text { young father with two children and he said exactly the same thing that we had suspected. Just } \\
\text { that while the bicycle paths are relatively well developed they could be better and that is all there } \\
\text { was to it }\end{array}$ \\
\hline
\end{tabular}

Figure 3. Remarks typical of the distancing student type (GD Global city, 129-211)

In the above excerpt, the students explicitly criticize what bothered them during the fieldwork and discuss what they would have liked instead. These students consistently reaffirm themselves and elaborate their responses mostly by exemplifying their remarks reciprocally. Despite their criticism, their comments always remain objective and unemotional. In the parallelized discourse organization, the object orientation of Type 2 students, in particular, is implicitly documented here. The students strive for place components that are clear-cut and visible to them (e.g. buildings) with a uni-directional focus on the physical-material space (Wardenga 2002).

Type 2 students distance themselves from insignificant aspects. This is shown linguistically by the fact that aspects of place are not dealt with in detail "other stuff") or dismissed in a judgmental mode ("was rather a little bit unnecessary"; "boring") or declared as false ("and then beating your brains out over it is also not 
right somehow"). It is not the people but rather the physical-material structures that make the Kotti what it is for them. As such, this becomes particularly evident in the personification of the buildings ("buildings express a lot"). The human ability to speak is attributed to the inanimate and makes the space "lively". The Kottbusser Tor in this orientation is an object which is equally accessible to everyone and furthermore reveals itself in the same way. Due to this fact, many of the students perceive it as "unnecessary" to explore on the spot and show disappointment ("and that is all there was to it") when the buildings are not dealt with in detail. Although the students strive towards a learning effect, they attach themselves to the physicalmaterial space, which inevitably leads to disappointment. For Type 2 students, local problem areas can be perceived directly with their own eyes ("you just have to eh look around you, turn $360^{\circ \prime \prime}$ ) or methodically with maps ("there you could also easily see"). Therefore, it is less necessary in this orientation to communicate with locals. Having the opportunity to see or discover something new through others is not considered since the protagonists, in the perception of the students, can see nothing more at Kotti than they themselves can. Consequently, anything that is not obvious is in-efficient in this orientation.

Type 2 representatives often talk in a judgmental mode, which is mainly criticaldistanced. They focus on aspects they would have been more interested in and therefore distance themselves from the actual purpose of the fieldwork. As a result, Type 2 students focus not on the locals but on the "bright side of life" and thus on what they regard as being worth striving for. Combined with the effectiveness and efficiency-oriented thinking which is characteristic of Type 2 students, this implicitly leads to isolation of those who are not able to comply. The objectives of the locals are of no greater significance to them. They do not feel addressed and distance themselves accordingly (GD Global city "we have no idea at all really what that life is like" or GD Einzellage "I think the topic itself was uninteresting for us at the moment since we don't really know so much about the big city"). This is also revealed by the fact that, contrary to the other types, less is said about the locals, neither from their point of view nor from the students' point of view. 


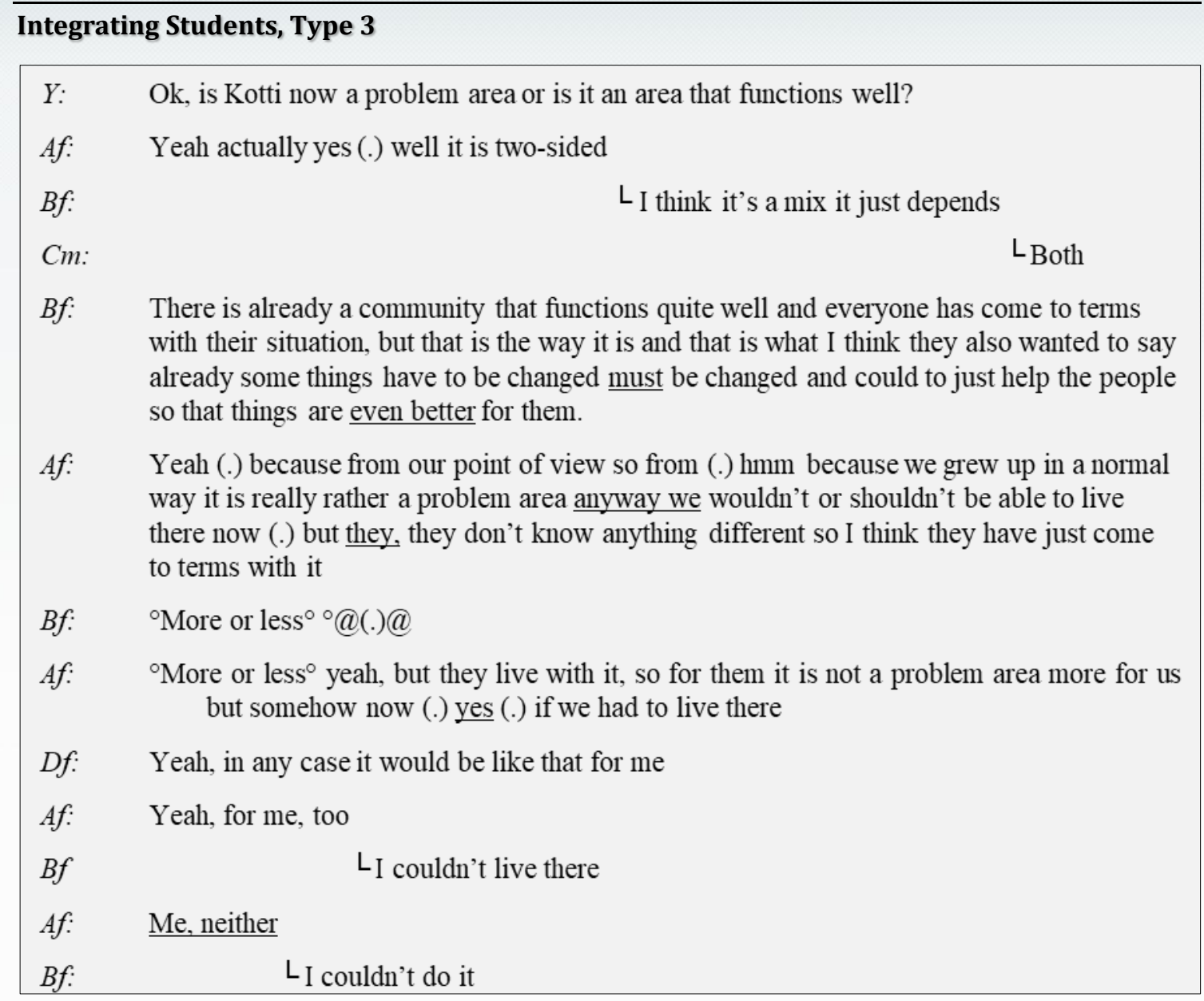

Figure 4. Remarks typical of the integrating student type (GD Weiler, 1208-1235)

Although the students acknowledge in the above excerpt that the image formed of Kotti depends on perspective, they remain in their own perspective when assessing it. The local community exists in the orientation of Type 3 students, because "everyone accepts their situation" or "they have come to terms with it". They embed this thinking in a horizon of normality to which their lives correlate ("we grew up in a normal way"), but not the lives of the residents. For Type 3 students, life at Kotti resembles a kind of fate to which one yields. This is shown, for example, by the repeated emphasis on the fact that they could not or would not like to live at Kotti. The fact it could be experienced or viewed differently by the residents is not taken into consideration. It is rather important to "help the people so that things are even better for them". Therefore, Type 3 students implicitly assume their understanding of the "good life" can be generalized which in turn shows they resort to their common sense (Nairn, 2005).

Type 3 students are oriented towards stability and security. In their eyes, it is desirable to remain within familiar structures. In assessing the local situation, Type 3 students primarily use their own point of view (GD Kleinstadt "somehow really sure I found you couldn't be here anyway, yeah, so we saw, for example, drugs and 
alcohol [...] and the streets were really gross"). Type 3 students tend to be described as an observer of perceptions. Besides the perceptions of others, their own are also considered. In this regard, they are ready to match their preconceived idea with a more in-depth look (Hope, 2009). They often question themselves and admit when they have jumped to hasty conclusions (GD Kleinstadt "In that I am I think really free of prejudice"). Compared to Type 1 students (characterized by mostly short and certain responses), those from Type 3 do not show certainty on a linguistic level, rather, they are characterized by long explanations and double-checking within the group (GD Weiler "was that well stated?" = security-seeking mode). In contrast to the excluding types, Type 3 representatives focus not on distancing or marginalization, but rather on inclusion. Based on the idea of a universal understanding of normal life, they distance themselves explicitly from anti-social and other forms of behavior which they do not tolerate (e.g. a non-existent sense of duty). Living side-by-side or together in a community appears completely feasible in this context. Their attempt to understand other perspectives becomes apparent, for example, in a further sequence when the students discuss the reasons why certain protagonists avoided them (GD Kleinstadt "the mother got out of our way because we because it was probably too unpleasant for her or she didn't want to talk about it and she just didn't trust us"). Students who are representative of Type 3 pursue the objective of helping and making improvements for the locals. Within this orientation, help is regarded as provided from outside (GD Weiler "to just help the people so that things are even better for them"). Thus, Type 3 students implicitly assume that the local people are unhappy with their lifestyle and are not in a position to independently improve their situation. It is a sense of compassion, which drives their actions. For Type 3 students, contact with the local people shifts the spatial planning issue from a distant, general to a close, personal level. 


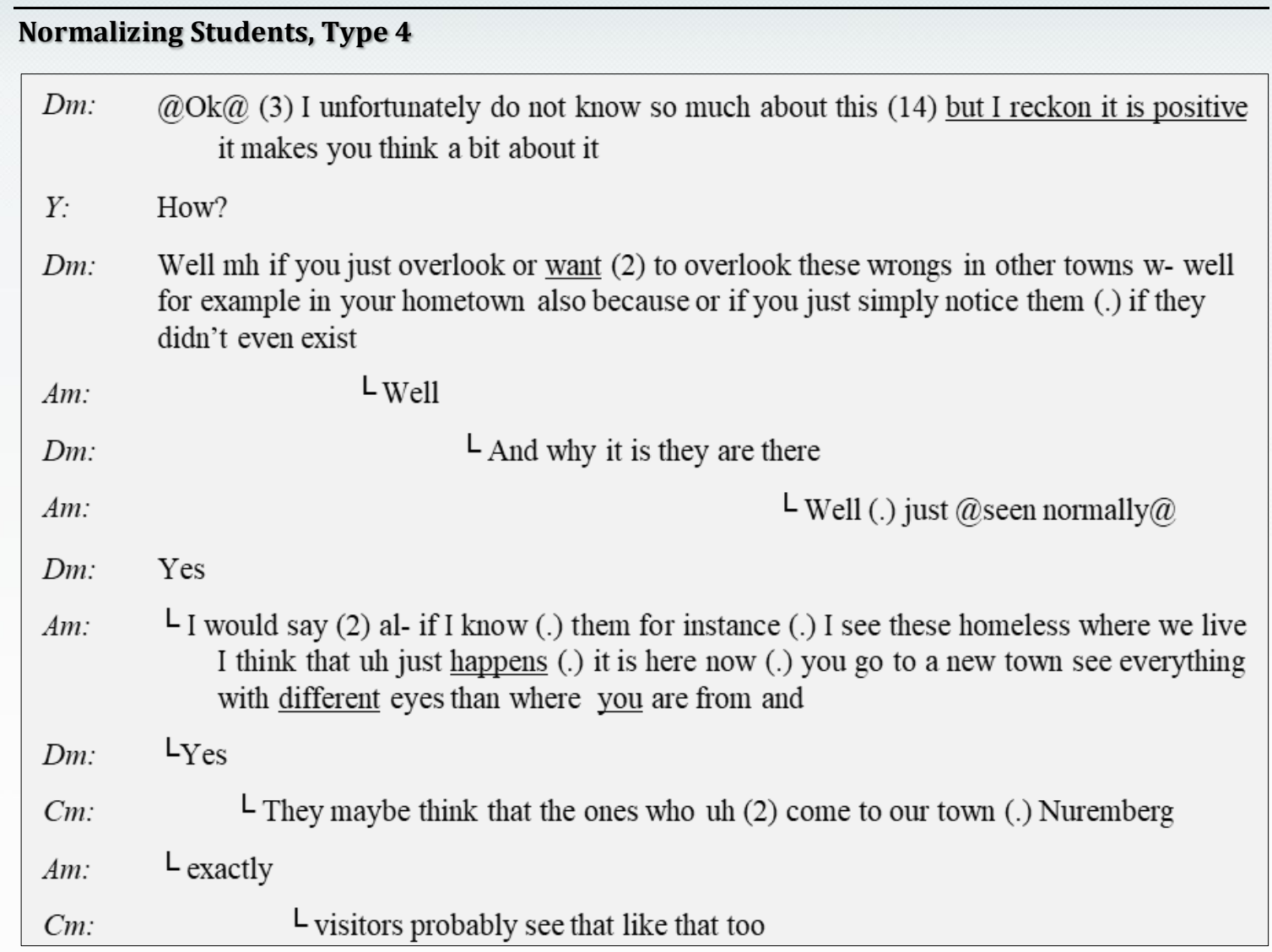

Figure 5. Remarks typical of the normalizing student type (GD Metropole, 998-1032)

In the above excerpt, the questioning of one's own and others' perceptions is documented. The reflection initiated through the fieldwork was emphasized positively by Dm. He elaborates a question raised for him on the example of his hometown ("[...] if you just overlook or want to overlook these wrongs [...] if they didn't even exist") and exemplifies this. Aspects that were previously perceived and labelled as "just happens" actively move into his horizon. In a new city "everything [is seen] with different eyes" provides a benefit for aspects which had not been perceived before. The experience gained during fieldwork proves useful in distancing from one's own view. From this meta-level, the "normal" is again seen as something "special" for these Type 4 students. Consequently, Type 4 students recognize their own observer dependency and the associated restrictedness of their observations.

Students who are identified as Type 4 perceive 'otherness' as an existing social reality and diversity as being the norm. Even though everyone is different for them, they are also equal ("unity in difference"). People will be noticed not only in spite of, but especially because of their distinctness. In contrast to the previous types, Type 4 representatives also recognize perspectives that contradict their own (GD Metropole "you just have to accept it and respect it"). Accordingly, categorical thinking is hardly given, rather the fundamental normality of everyone is emphasized. Since each individual is part of an entity, they endeavor to consider all 
perspectives (GD Megacity "it is not only about the homeless, but rather it is also that there are a lot of migrants there or unemployed people, who still need a flat anyway"). Type 4 students are explicitly aware of the benefits of considering several perspectives to achieve a differentiated assessment (GD Metropole "and I think more people would have come out of it if everyone had just been consulted together"). Distancing does not take place on a generalized level (whole groups), but rather on a level of individual behavior if this is perceived as undifferentiated and not authentic. This can be seen, for example, when Type 4 students distance themselves from the expert from the Kotti neighborhood association by assessing the expert's information as undifferentiated and unilateral. The students feel obliged to act with regard to the inclusion of other points of view as well as avoiding superficiality. Thus, conflicts, difficulties, and differences are not concealed or avoided, but rather emphasized. There is a willingness to face their own perspective with scrutiny and to accept aspects of concern only after questioning such views or experience.

Type 4 students experience the Kotti in alternating phases of dominance of space and place, predominantly as "confrontation place" with criminality and conflicts, as well as "participation place" within which gathering own experiences and forming own opinions is possible. They strive for experiential knowledge and integrate their experiences into this thought pattern. Accordingly, direct experience plays an important role for this type of identification (Hope, 2009). The knowledge Type 4 students want to acquire should be useful in their orientation. In comparison with other student types, Type 4 students described the fieldwork as being particularly positive in contrast to other geographical fieldwork or their daily geography classes. According to these students, it was possible to learn much more this way "than on normal fieldwork with a guide or on your own where you read something like in a museum" (GD Metropole). On an explicit level, this result is consistent with the indications of the importance of self-activity, which, from the students' perspective, has motivational (positive, affective reaction to fieldwork) and cognitive ("learning much more") effects (Bette et al., 2015b; Remmen \& Frøyland, 2014).

\section{Discussion and Conclusion}

The aim of the empirical research was to understand the way students encounter fieldwork in a deprived area from their point of view, and to reconstruct their existing orientations. The group discussions were highly autonomous and on average lasted for approximately one hour; the discussions were also predominantly emotional. As such, it indicates that students possessed a great need to talk because the fieldwork activity prompted them to deal intensively with the topic both cognitively and affectively (Oost et al., 2011). On a content level, the empirical findings show that different existing orientations result in different ways of dealing with the fieldwork experience. This shows the great potential of the methodological approach chosen in this paper. The orientations structure the student's thoughts concerning the problems of spatial planning presented to them. This result indicates the importance of taking learning conditions (in a broad sense, 
both explicit and implicit) into account when designing and implementing fieldwork that identifies deep subject-matter learning in deprived areas as a target level. Some of the students' orientations allow them to deal with the topic of the social city in the manner intended. This becomes particularly evident in the comparison of Type 4 students with Type 1 students. Type 4 students describe diversity as something normal in their orientation, they perceive - in contrast to Type 1 students - the problems of spatial planning in their diversity. Type 4 students, in particular, also develop abstract perspectives about the issue of development of deprived urban areas. Thus, the fieldwork underlines the great potential of working locally (Ellwood, 2004; Hope, 2009; Lee, 2020). A different learning process occurs when deprived urban areas are experienced vividly and in-situ compared to when students deal with them abstractly in the classroom (Elwood, 2004). Students confirm it was an important experience for them to see Kotti first-hand. However, whereas for Type 3 students it is personalization through encounter that provides access to the topic, it is the assumed authenticity of the experience that matters for Type 4 students. The experience seems to convey perceptions which generate emotions beyond the acquisition of geographical knowledge. These experiences, combined with the acquired geographical knowledge, can lead to a more comprehensive cognitive process for students. These students combine their prior knowledge, with their experiences at Kotti together with their everyday life. Moreover, such new experiences give the impetus to reflect on the experiences of students' in their hometowns. This use of and reflection on knowledge can thus be understood as an indicator for deep learning processes to occur during the fieldwork (Remmen \& Frøyland, 2014). In addition to subject-specific learning, it turned out that the major strengths of the fieldwork were that it raised student awareness about their perception of the environment as always being subjective. This result can be seen as consistent with Elwood (2004) and Hope (2009) who show that learning locally can challenge understanding because a lack of understanding becomes clear to the students as well as the complexity of geographical issues. With regard to the excluding-types (Types 1 and 2), this cannot be established. Apart from the positive experience of exploring neighborhoods away from tourist hotspots, fieldwork offers fewer opportunities to deal with spatial planning issues as well as own stereotypes. In this respect the finding is consistent with that of Nairn (2005), who stressed that the power of direct experience by itself is not sufficient to challenge their prior beliefs. Leaving the comfort zone (in the sense of entering a less familiar area) was hard, maybe even too hard for some students. The students had partial contact with the police or witnessed drug abuse at the Kotti. Especially in these situations, which are characterized by ambiguity, a construction of "otherness" can take place by referring to stereotypical perspectives. Overall, these results suggest that the emphasis on difference AND equality plays an important role (Type 4), because the emphasis on difference without equality tends to result in hierarchical thinking (Type 1). This becomes particularly apparent with regard to the including types (Types 3 and 4). Here, the critical engagement with "others" and also with one's own way of thought leads to uncertainty among the students, which seems to initiate the opportunity to allow alternative views. These results indicate that not only other perspectives need to be considered on a content level, but also one's own positioning and actions (Nairn, 2005). This appears to be a 
balancing act which some students do not succeed in, therefore, without deconstruction, a reproduction occurs. This is contrary to the intended learning process and also to the approach of the social city. Learning at Kotti does not seem to enable these students to reflect directly on the challenges of spatial planning in deprived areas and their stereotypes (Nairn, 2005). This insight is important insofar as the orientations in students' practice of action are inherent (Bohnsack, 2007; 2010). However, the consequences of ambivalence should not prevent teachers from conducting fieldwork especially as there is no empirical evidence so far which would indicate that better results are achieved in classroom settings. To negate such fieldwork in advance would be nothing more than a demonstration of power from a privileged position (for example, "we" decide that we do not go, and "we" also decide what is observable and what is not). On the other hand, these stereotypes do not disappear if we conduct classroom teaching - they might remain hidden, in response to allegedly successful teaching. Instead of this, the aim of subject-matter teaching should be to find strategies to make visible to students the implicit power structures and stereotypes, and to ensure their destabilization (Haversath \& Schrüfer, 2013). This was attempted by integrating various methodological approaches such as the role excursion and face-to-face interviews. It seems, however, there was much less support for some students which partly confirms the risk of personal responsibility in student-centered approaches (Fuller et al., 2006). Accordingly, the results of the current study support the argument that we explicitly need to instruct students to reflect on the processes involved (Elwood, 2004; Nairn, 2005). Consequently, reflective abilities cannot be assumed (Dummer et al., 2008), especially if what is to be reflected upon is implicit and not directly accessible. We accordingly assume that implicit knowledge must first be transformed into explicit knowledge so that blindspots become visible and thus perceptible. Becoming aware of one's own stereotypes and attitudes can therefore be seen as a prerequisite for destabilizing the simple reproduction of stereotypes. Consequently, this is a good starting point to address students' orientations and to make them reflect. A basic condition, however, seems to be that there is an openness on the side of the students to critically engage with the self (Elwood, 2004). Orientations are considered stable and not changed by a single fieldwork encounter, however, reflective processes are seen as a vehicle for change (Fögele, 2016). In this way, students can be questioned critically and encouraged to reflect upon their effect concerning geographical challenges. For this purpose, the typology offers great potential as reflective impulse and methodical tool (Fögele et al., 2019).

The findings show that a homogeneous teaching and learning concept has completely different effects in a heterogeneous study group (Dunphy \& Spellman, 2009; Hope, 2009; Rydant et al., 2013). This is not a new aspect because learning processes are usually constructive and not transmissive (Dunphy \& Spellman, 2009). Reflecting on the findings from the current study, the results should be used constructively. For example, the excluding-types tend to emphasize selfresponsibility which is a basic precondition of the social city model. Such conformity between the student orientations and the social city model can be used, for example, as a starting point because there is a link to the explicit and implicit knowledge of these students. This again implies the great potential of the typology, which can be used as a diagnostic tool to capture learning conditions. The results also indicates 
that both the follow-up of the fieldwork and its preparation, including critical reflection, are of great importance for the educational potential of fieldwork (Dummer et al., 2008; Remmen \& Frøyland, 2015). Accordingly, further research should be undertaken to explore how enhanced consideration of learning conditions (at both explicit and implicit levels) affects student learning on fieldwork. This finally leads to the question about how the learning envir onment must be designed to address and challenge the everyday knowledge and orientations demonstrated by different types of students. Therefore, the authors make the following recommendations:

\section{Preparation}

Destabilization of the difference emphasis (Hall, 2019): The "us and them thinking" (Nairn, 2005, p. 303) must move more into the background at the same time as the thematic level becomes more focused. An encounter with different life plans should therefore be initiated and discussed more intensively in the classroom (from talking about "others" to talking to individuals). In this context, the deficit logic reconstructed in various students' statements should also be addressed. Geography provides a suitable framework for the use of the principles of reconstruction, deconstruction and construction (Reich, 2010; Haversath \& Schrüfer, 2013). For example, a newspaper article about the Kotti, using stigmatizing or strong language, could be used intentionally. Since a newspaper article initially does not contain the students' stereotypes, this can also reduce the risk of not allowing reflexive processes as a measure of self-protection (Fögele et al., 2019). In addition, the collectivity of such stereotypes, that is stereotypes occurring not because individuals think badly, but because they are often culturally influenced (Fleischer, 2016); as well as their construction through spatial representations becomes transparent for the students. Lines of difference that could potentially become effective for the fieldwork activity could first be noted, and their effects reflected upon in order to give students the opportunity to question power relations. In a next step, for example, and guided by reflexive impulses from the teacher, an explicit search for what contradicts the stereotypes can be made by guiding one's attention to that which does not confirm one's own perception (Fögele et al., 2019). Alternatively, a search for similarities in less emotionally charged and studentrelated areas such as family life can also be made (Fleischer, 2016). By deconstructing possible stereotypes in advance, students might for example be confronted with them during the enactment of fieldwork in a slightly weaker way. This means that there are already alternative drafts to these stereotypes.

\section{Working in The Field}

The first question that arises about working in the field concerns how it will be possible to more strongly reflect stereotypes and power structures during the course of the fieldwork without reproducing them? (for example, how to avoid the danger of confirming stereotypes by naming them again from a position of authority, such as from the teacher). This poses a challenge with regard to the selection of protagonists for a change of perspective, which are freely chosen by the students in the sense of participant-centering (Hemmer \& Uphues, 2008). One approach is to let students establish well-founded criteria for selection of the protagonists and criteria 
about how to include their needs. In this way, potential blind-spots can be made visible and can be addressed offensively and reflexively from the beginning (for example, identifying which criteria were omitted by the students yet are important for the inclusion of the needs of the inhabitants). In addition, the students can be shown how much or little they know about life at Kotti, and accordingly, it can be jointly discussed how appreciative in-depth knowledge can be generated (Type 2). All in all, teachers need to pay close attention to the messages conveyed to students in the fieldwork area (Elwood, 2004; Dummer et al., 2008). Students may have never experienced similar situations before which can lead to uncertainty. They need careful guidance on how to deal with those uncertainties. Accordingly, the students' needs should addressed explicitly: The students may not be in danger at any time, but their (subjective) feeling of security must be taken into account (e.g., type 3). Even small tricks can be sufficient, such as providing them with certain strategies: If they feel very uncomfortable, they can also break off situations in a friendly manner. It therefore seems relevant during field activities to observe and advise at all times in order to alleviate extreme situations if necessary (teachers hands-on- and minds$\mathrm{ON}$ instead of OFF). Moreover, students must also accept when inhabitants are not willing to be interviewed. This should also be discussed and reflected in the run-up in order to jointly initiate understanding from the perspective of the inhabitants and to create a sensitivity for various causes. With regard to the value of authenticity (Type 4), careful selection and integration of informants seems to be particularly relevant. If students are to be encouraged to take a differentiated perspective on geographical issues, information must also be made available in a differentiated manner. The Quartiersmanagement experts can also be used to establish a contact with suitable interview partners. By using this expertise, for example, it is possible to find willing residents for face-to-face contact in the area of homeless people (even if aggressive behavior should certainly not be understood as a standard, this can potentially occur through drug and alcohol consumption, so that negative experiences can be prevented and a stereotyping can be avoided). In addition, a stronger involvement of experts can be achieved by using their experience in dealing residents of the Kotti area (for example, what strategies do students have to get into conversation with inhabitants?). Furthermore, examples should be included on how to get in touch with residents. A demonstration of self-power by the inhabitants instead of the perceived illustration of otherness might be challenging moments for students (Type 3). It might also be important for those Type 3 students who argue that they cannot imagine life in Kotti to see if the inhabitants of Kotti will be available for some form of discussion.

\section{Debriefing}

After the actual fieldwork, it is necessary to intensively reflect on its concept again at a meta-level in the classroom (Elwood, 2004; Remmen \& Frøyland, 2015). The learning process of those involved can be made visible (Favier \& van der Schee, 2009). Students who have difficulty in relating their individual experiences with complex questions behind the individual case need special support (Nairn, 2005). The typology and related exemplary citations should be presented to students and discussed with them. In so doing, it gives students, in Luhmann (1990) terms, an observation of the second order or sense of "looking over your own shoulder", and 
hence an opportunity for self-diagnosis. Students can independently assign themselves to a type without having to expose their attitudes in front of their classmates. As such, this enables students to independently recognize their own strengths and weaknesses, and will also tend to increase the necessary openmindedness towards self-reflection (Dewey, 1910). Meanwhile, there is an array of empirical evidence on the effectiveness of instructional meta-relaxion in the context of comparable topics (Hofmann, 2015).

\section{References}

Applis, S., Hofmann, R., \& Höhnle, S. (2015). Zur dokumentarischen Methode in der geographiedidaktischen Forschung. In A. Budke, A. \& M. Kuckuck (Eds.), Geographiedidaktische Forschungsmethoden (pp. 243-268). Münster: LIT.

Atrache-Younes, L., Bosa, N., \& Hise, T. (2017). Integriertes Handlungs-und Entwicklungskonzept 2017-2019. Quartiersmanagement Zentrum Kreuzberg/ Oranienstraße. Berlin. Retrieved from: https://www.quartiersmanagementberlin.de/fileadmin/content-media/Handlungskonzept_2017/IHEK_201719_QM_ZKO.pdf

Becker, H., \& Löhr, R.-P. (2002). „Soziale Stadt“- Ein Programm gegen die sozialräumliche Spaltung in den Städten. In Bundeszentrale für politische Bildung (Ed.), Stadt und Gesellschaft. Berlin. Retrieved from: http://www.bpb.de/politik/innenpolitik/stadtund-gesellschaft/75720/grundlagen

Beer, I., \& Musch, R. (2003). Berlin-Kreuzberg - Kottbusser Tor. in deutsches Institut für Urbanistik, soziale Stadt. Berlin. Retrieved from: www.biwaq.de/StBauF/SharedDocs /Publikationen/StBauF/SozialeStadt/0161_zwischenbilanz.pdf?_blob=publicationF ile\&v $=1$

Bette, J., Hemmer, M., Miener, K., \& Schubert, J.C. (2015a). Das geographische Interesse von Schülern an einer Klassenfahrt nach Berlin. Praxis Geographie, 9, 46-48.

Bette, J., Hemmer, M., Miener, K., \& Schubert, J.C. (2015b). Welche Arbeitsweisen interessieren Schüler auf Exkursionen. Praxis Geographie, 7(8), 62-64.

Bock, C., \& Pappenberg, U. (2018). Erhebung. In C., Bock, U., Pappenberg, \& J. Stollmann (Eds.) Das Kotti Prinzip. urbane Komplizenschaft zwischen Räumen, Menschen, Zeit, Wissen und Dingen. TU Berlin; http://dx.doi.org/10.14279/depositonce-7472

Bohnsack, R. (2007). Rekonstruktive Sozialforschung: Einführung in qualitative Methoden. Opladen: Budrich.

Bohnsack, R. (2010). Documentary method and group discussions. In Bohnsack, R., Pfaff, N., Weller, V. (Eds.), Qualitative analysis and documentary method in international educational research (pp. 99-124). Opladen: Burdrich.

Böing, M., \& Sachs, U. (2009). Die Rollenexkursion. Ein neues Format in der Exkursionsdidaktik. Geographie und Schule, 179, 33-40.

Bourdieu, P. (1997). Zur genese der Begriffe Habitus und Feld. In P. Bourdieu (Hg.), Der tote packt den lebenden (pp. 59-78). Hamburg: VSA-Verlag.

Boyle, A., Maguire, S., Martin, A., Milsom, C., Nash, R., Rawlinson, S., Turner, A., Wurthmann, S., \& Conchie, S. (2007). Fieldwork is good: the student perception and the affective domain. Journal of Geography in Higher Education, 31 (2), 299-317. DOI: 10.1080/03098260601063628 
Dannenberg, P. (2013). Neue Herausforderungen und perspektiven für Berlin. Geographische Rundschau, 65, 4-11.

Dewey, J. (1910). How we think. Chicago: D. C Heath \& Co Publishers

Dummer, T. J. B., Cook, I. G., Parker, S. L., Barrett, G. A., \& Hull, A. P. (2008). Promoting and assessing 'deep learning' in geography fieldwork: an evaluation of reflective field diaries. Journal of Geography in Higher Education, 32 (3), 459-479. DOI: 10.1080/03098260701728484

Dunphy, A., \& Spellman, G. (2009). Geography fieldwork, fieldwork value and learning styles. International Research in Geographical and Environmental Education, 8 (1), 1928. DOI: $10.1080 / 10382040802591522$

Eltges, M., \& Kocks, M. (2015). Integrierte Ansätze in der räumlichen Planung. Das Programm soziale Stadt. ein Blick zurück und nach vorne. Informationen zur Raumentwicklung, 3, 287-300.

Elwood, S. (2004). Experiential learning spatial practices and critical urban geographies. Journal of Geography, 103, 55-63. DOI: 10.1080/00221340408978576

Favier, T., \& van der Schee, J. (2009). Learning geography by combining fieldwork with GIS. International Research in Geographical and Environmental Education, 18 (4), 261-274. DOI: $10.1080 / 10382040903251091$

Findling, E. (Ed., 2003). Geschichte wird gemacht! Berlin am Kottbusser Tor. Lesebuch, Fotoband und CD-Rom. Dokumentation der gleichnamigen Dauerausstellung im Kreuzberg Museum. Berlin: Selbstverlag.

Fleischer, E. (2016). Der anti-bias-ansatz als Methode politischer Erwachsenenbildung. In Magazin erwachsenenbildung.at. Das Fachmedium für Forschung, Praxis und Diskurs. 28, Wien.

Fögele, J. (2016). Entwicklung basiskonzeptionellen Verständnisses in geographischen Lehrerfortbildungen. Rekonstruktive Typenbildung, relationale Prozessanalyse, responsive Evaluation. geographiedidaktische Forschungen (Band 61). Münster: Monsenstein und Vannerdat.

Fögele, J., Hofmann, R., \& Mehren, R. (2014). Tablet-based fieldwork: opportunities and challenges of mobile learning for geography education. In R. Vogler, A. Car, J. Strobl \& G. Griesebner (Eds.), GI_Forum 2014. Geospatial Innovation for Society (pp. 332-343). Berlin: Vde.

Fögele, J., Hofmann, R., Luber, L., \& Mehren, R. (2016). Das Kottbusser tor in Berlin. Rekonstruktion von Schülerorientierungen im Rahmen einer geographischen Arbeitsexkursion in einem Problem Bezirk. Geographie aktuell und Schule, 220 (38), 11-20.

Fögele, J., Luber, L., \& Mehren, R. (2019). Types of student teachers between theory and practice in the subject of geography. reconstructing orientations using the example of a seminar on experiments. Journal of Geography in Higher Education, 6(5), 1-24. DOI: $10.1080 / 03098265.2019 .1698524$

Fuller, I. C., Gaskin, S., \& Scott, I. (2003). Student perceptions of geography and environmental science fieldwork in the light of restricted access to the field, caused by foot and mouth disease in the UK in 2001. Journal of Geography in Higher Education, 27 (1), 79 -102. DOI: 10.1080/0309826032000062487 
Fuller, I., Edmondson, S., France, D., Higgitt, D., \& Ratinen, I. (2006). International perspectives on the effectiveness of geography fieldwork for learning. Journal of Geography in Higher Education, 30 (1), 89 -101. DOI: 10.1080/03098260500499667

Gryl, I. (2013). Geographielehrende: Biographie und Kompetenzentwicklung. In D. Kanwischer (Ed.), Studienbücher der Geographie. Geographiedidaktik: ein Arbeitsbuch zur Gestaltung des Geographieunterrichts; mit 4 Tabellen (pp. 70-80). Stuttgart: Borntraeger.

Hall, K. I. (2019). Teaching for equity and justice: Methods and best practices of effective anti-bias educators. Webster University: ProQuest Dissertations Publishing.

Haversath, J.-B., \& Schrüfer, G. (2013). Vorurteile und Stereotype. In D. Böhn, Obermaier, G., (Eds.), Wörterbuch der Geographiedidaktik. Begriffe von $A-Z$ (pp. 286-288). Braunschweig: Westermann.

Helsper, W. (2018). Vom Schülerhabitus zum Lehrerhabitus. Entwurf eines Theorie- und Forschungsprogramms. In M. Rothland \& M. Lüders (Eds.), Lehrer- BildungsForschung. Festschrift für Ewald Terhart (pp. 61-76). New York: Waxmann.

Hemmer, I., \& Hemmer, M. (2010). Interesse von Schülerinnen und Schülern an einzelnen Themen, Regionen und Arbeitsweisen des Geographieunterrichts - ein Vergleich zweier empirischer Studien aus den Jahren 1995 und 2005. In. Hemmer, I. \& Hemmer, M. (Eds.), Schülerinteressen am Themen, Regionen und Arbeitsweisen des Geographieunterrichts. Ergebnisse der empirischen Forschung und deren Konsequenzen für die Unterrichtspraxis. Weingarten: Selbstverlag, 65-148.

Hemmer, M., \& Uphues, R. (2008). Zwischen Kiez und Metropole - geographische Schüler Exkursionen in Berlin und Umgebung. Protokolle, ausgearbeitete Schüler Exkursionen und Materialien der fachdidaktischen Berlin-Exkursion 2007. Münster.

Hofmann, R. (2015). Urbanes räumen. Pädagogische Perspektiven auf die Raumaneignung Jugendlicher. Bielefeld: transcript.

Hope, M. (2009). The importance of direct experience: a philosophical defence of fieldwork in human geography. Journal of Geography in Higher Education, 33(2), 169-182. DOI: 10.1080/03098260802276698

Kent, M., Gilbertson, D.D., \& Hunt, C.O. (1997). Fieldwork in geography teaching: a critical review of the literature and approaches. Journal of Geography in Higher Education, 21(3), 313-332. DOI: 10.1080/03098269708725439

Kern, E., \& Carpenter, J. (1986). Effect of field activities on student learning. Journal of Geological Education, 34,180-183.

Kleemann, F., Krähnke, U., \& Matuschek, I. (2013). Interpretative Sozialforschung. eine Einführung in die Praxis des Interpretierens. Wiesbaden: Springer VS.

Krings-Heckemeier, M.-T., \& Pfeiffer, U. (1998). Überforderte Nachbarschaften. soziale und ökonomische Erosion in Großsiedlungen. In GdW Bundesverband deutscher Wohnungsunternehmen e.V. (Ed.), Überforderte Nachbarschaften. Zwei sozialwissenschaftliche Studien in den alten und den neuen Bundesländern (pp.19 162). GdW Schriften 48. Köln: Selbstverlag.

Lamnek, S. (2005). Gruppendiskussion. Theorie und Praxis. Weinheim: Beltz.

Lane, R., \& Coutts, P. (2015). Working with students' ideas in physical geography: a model of knowledge development and application. Geographical Education, 28, 27-39. 
Lee, J. (2020). Designing an inquiry-based fieldwork project for students using mobile technology and its effects on students' experience. RIGEO, 10 (1), 14-39. DOI: 10.33403rigeo.637666

Loos, P., \& Schäffer, B. (2001). Das Gruppendiskussionsverfahren. Theoretische Grundlagen und empirische Anwendung. Opladen: Leske + Budrich.

Lössner, M. (2011). Exkursionsdidaktik in Theorie und Praxis. Forschungsergebnisse und Strategien zur Überwindung von hemmenden Faktoren. Ergebnisse einer empirischen Untersuchung an mittelhessischen Gymnasien. Geographiedidaktische Forschungen, 48. Weingarten: Selbstverlag.

Luber, L. (2015). Brennpunkt Kottbusser Tor - Rekonstruktion von Schülerorientierungen im Anschluss einer Exkursion. Wissenschaftliche Hausarbeit im Rahmen der ersten Staatsprüfung für das Lehramt an Gymnasien im Fach Geographie. Gießen: University. (Unveröffentlicht)

Luhmann, N. (1990). Die Wissenschaft der Gesellschaft. Frankfurt a.M.

Mannheim, K. (1980). Eine soziologische Theorie der Kultur und ihrer Erkennbarkeit: konjunktives und kommunikatives denken; über die Eigenart kultursoziologischer Erkenntnis. Frankfurt am Main.

Moritz, B. (2016). Vom Nutzen der dokumentarischen Methode. Überlegungen zur empirischen Erforschung von außerschulischen Lernorten in der politischen Bildung. In Deichmann, C \& May M. (Eds.) Politische Bildung. Wiesbaden: Springer, 185-200.

Nairn, K. (2005). The problems of utilizing "direct experience" in geography education. Journal of Geography in Higher Education, 29 (2), 293-309. DOI: $10.1080 / 03098260500130635$

Nentwig-Gesemann, I. (2013). Die Typenbildung der dokumentarischen Methode. In R. Bohnsack, I. Nentwig-Gesemann, \& A.-M. Nohl (Eds.), Die dokumentarische Methode und ihre Forschungspraxis. Grundlagen qualitativer Sozialforschung (pp. 295-323). Wiesbaden: VS.

Oost, K., De Vries, B., \& van der Schee, J. (2011). Enquiry-based fieldwork as a rich and powerful teaching strategy - school practices in secondary geography education in the Netherlands. International Research in Geographical and Environmental Education, 20 (4), 309-325. DOI: 10.1080/10382046.2011.619808

Pawson, E., \& Teather, E. K. (2002). 'Geographical expeditions': assessing the benefits of a student-driven fieldwork method. Journal of Geography in Higher Education, 26 (3), 275-289. DOI: 10.1080/0309826022000019864

Przyborski, A., \& Wohlrab-Sahr, M. (2009). Qualitative Sozialforschung. Ein Arbeitsbuch (2. Aufl.). München: Oldenbourg.

Reich, K. (2010). Systemisch konstruktivistische Pädagogik. (6. Aufl.). Neuwied: Beltz.

Reichertz, J. (2013). Gemeinsam interpretieren. Die Gruppeninterpretation als kommunikativer Prozess. Wiesbaden: Springer VS.

Remmen, K. B., \& Frøyland, M. (2014). Implementation of guidelines for effective fieldwork designs: exploring learning activities, learning processes, and student engagement in the classroom and the field. International Research in Geographical and Environmental Education, 23 (2), 103-125. DOI: 10.1080/10382046.2014.891424

Remmen, K. B., \& Frøyland, M. (2015). What happens in classrooms after earth science fieldwork? Supporting student learning processes during follow-up activities. 
International Research in Geographical and Environmental Education, 24 (1), 24-42. DOI: $10.1080 / 10382046.2014 .967114$

Richter-Rethwisch, S. (2014). Der neue Häuserkampf in Berlin. Wie können Stadtplanung und Wohnungspolitik ein recht auf Stadt" ermöglichen? Masterarbeit, Hafen City Unviersität Hamburg.

Rydant, A.L., Cusack, C., Smith, J.P., Shiplee, B.A., \& Middelkauff, B. (2013). Student perceptions of fieldwork utility across three international field courses. RIGEO, 3 (2), 189-203. Retrieved from: http://rigeo.org/vol3no2/RIGEO-V3-N2-5.pdf

Scott, J. (1992). Experience. In J. Butler \& J. W. Scott (Eds.), Feminists theorize the political (pp. 22-40). New York: Routledge.

Sieben, S (2010). Ethnische Segregation und interkulturelle Stadt Entwicklung im Ruhrgebiet. Geographische kommission für westfalen. Retrieved from: https://www.lwl.org /LWL/Kultur/Westfalen_Regional/Bevoelkerung/Segregation_Ruhrgebiet

Tonts, M. (2011). Using problem-based learning in large undergraduate fieldwork classes: an Australian example. International Research in Geographical and Environmental Education, 20 (2), 105-119. DOI: 10.1080/10382046.2011.564784

Walther, U.-J. (2007). Das Programm "Die Soziale Stadt". In Bundeszentrale für politische Bildung (Ed.), Stadt und Gesellschaft. Berlin. Retrieved from: http://www.bpb.de/politik/innenpolitik/stadt-undgesellschaft/64444/einfuehrung

Wardenga, U. (2002). Alte und neue Raumkonzepte für den Geographieunterricht. Geographie heute, 23(200), 8-11.

\section{Appendix}

\section{Appendix 1: Transcript “Group Metropole"; Opening Passage}

Am: Yes well: on the whole it has been actually quite good so: you have seen Berlin in a completely different way, not always these (.) sights, but also really, so in the neighborhoods like this everything is running, the problems, the conflicts and (.) oh oh that was a nice insight

Bf: Umm yes: that was (.) something else so I thought it was okay too: but (.) so this thing with these posters we wrote there. I found it a bit ridiculous so $\mathrm{mh}$ mh you don't need $\mathrm{w}$ - well and (.) yes (.) but it was really nice

Cm: Yes, I also reckon it quite great actually umm (.) you now also saw a different quarter than these umm (.) yes, these standard neighborhood like Berlin umm, umm, like the Branden burger gate or something. (.) umm but simply poorer quarters (.) and yes

Dm: So, I found the ex- information from the experts have been repeated relatively often, you have not heard very much differentiated. But from the people who were there, if they said something contrary to the sellers, you have already heard something

Y: $\quad \mathrm{Ok}$

Cm: $\quad{ }^{\circ} Y e s(\text { great })^{\circ}$

Y: Yes, then tell me (.) how were your experiences were, what have you experienced everything

Dm: I think the woman at the (.) Kotti e.V. wasn't really (.) useful at all because 
Cm: $\quad$ LShe talked more with our teacher

Dm: $\quad$ LYes, more with (.) she talked a lot more with Mr. XY and in our group, hardly anyone really asked questions (2) Well, it wasn't so much of a banger (.) really, towards the end

Am: Well, that part was actually ok for our group, so I guess (.) they tried, she tried to give us information like conflicts, projects, how everything works, so they gave us nice (.) cards like this: so I actually thought it was: (.) they have tried and I thought it was actually quite ok. I had (.) actually no problem with that

Bf: $\quad$ So, I was at the Kotti, too, and (.) this woman umm so yes. The woman only said something when we asked her and I think (.) yeah, we can't know anything about it so from the beginning she should have talked a little more by herself so we can also ask more questions

Cm: $\quad{ }^{\circ} \mathrm{Yes}^{\circ}$

Am: At the end I still found it funny so: that we had to do an interview so: (.) and (.) $\mathrm{mh}$ that went a little wrong with our group because the people we (.) asked were busy most of the time

Dm: $\quad$ LBut we could only ask people who were working because otherwise we wouldn't know if they were doing what we were supposed to ask.

Am: $\quad$ LYes (2) but that was actually a quite (.) nice idea I reckon so

Dm:

LYes sure

Am: Yes, and I also found it quite nice actually that we had the freedom to move around the neighbourhood a bit

Dm; Yep

Cm: So that we were allowed to also say our own opinion on what we think of the uh quarter (.) uh (3) yes

\section{Formulating interpretation}

Main topic: First assessments regarding the fieldwork

Am: Am thinks the fieldwork is "actually quite good" because he saw Berlin in a "completely different" way, "not [as] always" the sights, but "as it really is" since problems and conflicts were also included.

Bf: $\quad$ Bf articulates that it was "something else" which she rated as "okay" in generel. However, she considers "this thing" with "these posters a bit ridiculous" because she doesn't see the benefit.

Cm: $\quad$ For $\mathrm{Cm}$ it is "quite great" to see something different than "these standard quarters", i.e. "poorer quarters".

Dm: Dm adds that the information from the experts "ha[ve] been repeated relatively often", so that you did not hear "very much differentiated" information about the quarter. However, you have received information from the people at Kotti. 
Y:

Cm:

Y: The Interviewer asks about the experience from the fieldwork.

Dm: Dm thinks the woman from the expert talk at Kotti e.V. did not help them.

Cm: Cm states that she talked more with her teacher.

Dm: Dm affirms this and goes on to say that "hardly anyone here really asked questions". That is why it was not "a banger" for him.

Am: Am adds that the woman "tried" to give them information. Accordingly, he judged her to be "quite ok".

Bf: Bf explains that the woman only said something when they asked her. She also reckoned that the students could not have the information of their own. The woman should have told them more about her own initiative.

Cm: Cm agrees.

Am: Am describes the fact that they had to do an interview as "funny". He says it went a bit wrong because people were busy.

Dm: Dm explains that the students could only have questioned the workers because they could only identify them through this.

Am: Am thinks the idea is "nice".

Dm: Dm confirms.

Am: The "freedom" to move around the neighbourhood is "actually quite good" for Am.

Dm: Dm validates this.

Cm: Cm liked that "we could also say our opinion".

\section{Reflective Interpretation}

Proposition by Am, who judged the fieldwork as positive (quite good, nice insight) which he proves by the fact that Berlin had been seen "as it really is" - for him it was more authentic. With this positive counter-horizon, the negative, the superficial view of the city ("not always these [...] sights") appeared at the same time. This already documents a first positive orientation towards differentiation (related to spaces). The cautious formulations (actually, completely) could stand for a scanning of the group since Am does not yet want to position himself too clearly to be able to relativize his statement if the remaining group members deviate from his feelings. When comparing the transcripts, it can be seen across all cases that the young people all choose cautious formulations at the beginning. In addition to the mentioned aspect of scanning the conjunctive experience, the formal situation with an interviewer could also play a role here. Bf connects to the fieldwork in the same mode as Am by first making an overall assessment of the fieldwork and then 
carrying it out. However, she distances herself to a certain extent. So "this thing with these posters" was "ridiculous". What she does not need, in her opinion, is devalued and thus represents an unsuitable orientation content. $\mathrm{Cm}$ ignores the statement of Bf by emphasizing the positive aspect of the fieldwork like Am and illustrates Am's statement in other words. Dm's statement that the expert lecture did not produce much differentiation supplements the orientation content raised by Am (differentiation now related to contents/knowledge). Questioning the people on site is seen as a contrast to the lecture by Dm- they therefore serve as an orienting element. While the information from the expert would not be sufficient, you could "already hear something" through the real contact to the actors. In addition, a positive orientation towards the acquisition of knowledge is documented, which explicitly reveals itself on a linguistic level (information, experience). In their first speeches, the learners implicitly address their role as students. Thus, they see themselves primarily in a passive role. Authentic and differentiated information should be presented to them. The interviewer $(\mathrm{Y})$ further stimulates the narrative of the students through an impulse question. Dm, who responds to Y's generally formulated narrative call, specifically addresses the expert discussion again. It emerges as the central topic. This is followed by a highly interactive density section. For Dm the conversation "wasn't really useful". Cm elaborates Dm's statement by confirming it through explanations. The negative aspect is the expert's focus on the teacher. The learners therefore have a clear idea of what is good for them. Dm validates $\mathrm{Cm}$ 's statement and also criticizes the fact that no new knowledge has been acquired which is evident from the fact that in the end it "wasn't a banger" for him. Hardly anyone asked questions - he would have wished for more [here Dm attributes a more active role of students]. Once again, the positive orientation towards the acquisition of knowledge is evident. Am relativizes the previous statements ("actually it was okay") by highlighting the expert's efforts to share the information. Here, as in other passages before, it becomes apparent that the young people are interested in articulating their own opinions. Am accepts to contradict the other group members on an explicit level on this topic. Bf, for whom it is also relevant to present their own opinion ("I was at the Kotti, too"), attributes the missing benefit of the conversation externally. In her opinion, asking questions would not have been possible because "the woman [...] should have talked a little more by herself ". This can be seen as a rejection of guilt. $\mathrm{Cm}$ validates the statement. A striving for knowledge becomes apparent, too. The students want to ask questions ("can") to learn more.

Am deals with the interview which he describes as "funny". So, working independently was fun, but it didn't work out perfectly. An external reason is given again: The actors "were mostly busy". Dm elaborates on this in the following and thus once again takes the responsibility away from the students. Am confirms and 
evaluated after a short break by describing the idea as nice. In the course of the group discussion, it repeatedly becomes apparent that the students criticize the idea, but do not try to make the impression that they did not like the fieldwork. Am feels positive about the "freedom", i. e. being unrestricted, as the students were able to move freely in the neighborhood. Dm confirms this. $\mathrm{Cm}$ states that it was positive that the students could say their own opinion. In this context, it can be seen that to the students not only the presentation of their own opinion seems important, but also its formation. The discourse organization can be described as parallelizing. Basically, this passage shows that a differentiated presentation of spaces and contents as well as the acquisition of knowledge has orientation potential for the young people. At this point, the comparative analysis follows, by means of which the orientations are specified. In this case, the comparison showed that the students are particularly oriented towards experiential or practical knowledge. They can gain this knowledge by either basing it on their own experience or by classifying the informant who passes it on in an authentic way.

\section{Biographical Statements}

Laura LUBER is a PhD candidate at the Department of Geography, Subject-matter education of Geography, University of Giessen, Germany.

Janis FÖGELE is a professor at the Department of Geography, Subject-matter education of Geography, University of Hildesheim, Germany.

Rainer MEHREN is a professor at the Department of Geography, Subject-matter education of Geography, University of Giessen, Germany. 